\title{
EFFECTIVENESS OF RISK CAPITAL (OWN FUNDS) IN THE POLISH BANKING SECTOR IN THE YEARS OF 2002-2016
}

\author{
Aleksandra Nocoń ${ }^{1}$, Irena Pyka ${ }^{2}$ \\ ${ }^{1,2}$ Department of Banking and Financial Markets, Faculty of Finance and Insurance, \\ University of Economics in Katowice, 1 Maja 50, 40-287 Katowice, Poland \\ E-mail: '1aleksandra.nocon@ue.katowice.pl (corresponding author); ${ }^{2}$ irena.pyka@ue.katowice.pl
}

\begin{abstract}
The analysis of effectiveness of risk capital in the Polish banking sector have become the main aim of the study. In the article, statistical and econometric methods were used, based on a linear regression model of net profit in relation to the value of own funds of the banking sector in Poland in the years of 2002-2016. Next, through the quartile method, there were estimated the relations between effectiveness and a level of risk capital of the largest banks in Poland. Conducted research were aimed to verify the research hypothesis stating that in the Polish banking sector there is a positive correlation between net profit and banks' own funds, which constitute an essential component of bank risk capital.
\end{abstract}

Keywords: risk capital, bank's own funds, effectiveness of risk capital, regression model, Polish banking sector, effectiveness of a banking sector.

JEL Classification: G21, G32.

\section{Introduction}

Bank risk is a subject of broad interest in scientific research and numerous publications due to the consequences that it causes in the financial system and the economy (Boyd \& De Nicoló, 2005; Apostolik, Donohue, \& Went, 2009; Bessis, 2015; Altunbas, Manganelli, Marques-Ibanez, 2011; Županović, 2014; Jajuga, Karaś, Kuziak, \& Szczepaniak, 2017; Marcinkowska, 2010; Moreno, 2006; Altunbas, Binici, \& Gambacorta, 2017; Szustak, 2017). Its active management favors the creation of risk capital, which in banks is of particular relevance and has different sources of its origin, application and also serves various purposes. Risk capital in a bank can also be interpreted in a different way, as it arises both through risk retention and through its transfer. The study focuses on the retention of bank risk and, therefore, informed decision-making about taking over consequences of random events in the case of their occurrence. Risk retention in banks does not mean passive waiting for its consequences. Banks accumulate funds in various forms to cover expected risk, for the most part, being the result of external events - prudential regulations of banking supervision and requiring risk exposure, its measurement, and finally also accurate calculations.

The main research subject of the study are own funds of modern banks and the changes taking place under the influence of risk retention. Although they constitute only a part of bank risk capital, they perform very important functions. Banks, by their essence based in operating activity on high leverage, are interested in minimizing their own funds. Maintaining a high level of bank risk capital reduces, therefore, their effectiveness and decreases investment profitability of their owners.

After the global financial crisis the document, commonly referred as Basel III, strongly tightened the capital requirements for banks. Significant changes concern not only new capital buffers, increasing banks' own funds, but also focus on their greater adequacy in terms of bank risk, regularities of measurement or, finally, an increase in the quality and transparency of equity. In this way, a banking sector is a subject to more restrictive regulatory discipline, and the change of banking supervisor's attitude to the method of bank risk control, finds its direct reflection in the demand for bank capital, adjusting the rate of return on financial investments. Low profitability of bank investments, declining growth of net profit and falling efficiency of bank capital constitute a justification and an important plane for the conducted research.

The main aim of the study was focus to analyze and assess the effectiveness of risk capital in the Polish banking sector. The level and structure of risk capital are determined by the decisions of the Polish banking supervision (currently the Polish Financial Supervision Authority) and the 
National Bank of Poland, although regulations of the Basel Committee on Banking Supervision and the directives of the European Parliament and of the Council are strictly respected by these national financial institutions (Marcinkowska, 2010). Therefore, risk capital in the Polish banking sector is created on principles applicable in other European Union countries. The carried out empirical research, covering the years of 2002-2016, are aimed at identifying the relations arising between bank funds and net profit. The research period of the conducted analysis comprised three research sub-periods, in which the orientation on the issue of capital requirements varied. The empirical research was directed to verification of the research hypothesis stating that in the Polish banking sector there is a positive correlation between net profit and banks' own funds, which constitute an essential component of bank risk capital.

\section{Risk capital, and banks' own funds. The concept, previous research and literature review}

Risk capital, otherwise also defined as capital for risk, is usually identified with financing securing the negative effects of risk (Duliniec, 2011). Its essence concerns to the conscious decision of the economic entity taking over the consequences of random events in case of risk occurrence. Therefore, the concept of risk capital is not new (Merton \& Perold, 1993a, 1993b; Matten, 2000; Culp, 2002a, 2002b; Doherty, 2005, 2000; Ishikawa, Yamai, \& Ieda, 2003), although it is still up-todate due to the dynamically developing Risk Management Theory (Banks, 2004; Graham, 2008; Rejda, 2001; Williams Jr. \& Heins, 1989; The Conference Board of Canada, 2003; Klimczak, 2007; Purdy, 2010; Versluis, 2011; Dionne, 2013; European Standard, 2010; Kaplan \& Mikes, 2016; Ennouri, 2013; Schieg, 2006; OECD, 2014), including the methods of its measurement and limitations (Ratliff \& Hanks, 1992; Vaughan \& Vaughan, 2003; European Standard, 2010; The National Archives, 2017; Jajuga et al., 2017; Protivity, 2006; Iacob, 2014; McCuaig, 2008).

Risk capital plays an important role in banking enterprises, which activity has always been associated with high risk due to a credit money creation mechanism and a method of financing operating activity. Nowadays, banks are characterized by a highly developed risk management system, mainly focused on maintaining risk within the accepted tolerance level (van Greuning \& Brajovic Bratanovic, 2009; Pyle, 1997; Żółtkowski, 2017; Aaron, Armstrong, \& Zelmer, 2012; Santomero, 1997). This means that capital for bank risk secures primarily its negative but only recognizable, and therefore expected financial consequences. By that means, identified risk capital refers to the concept of R. C. Merton and A. F. Perold (Merton \& Perold, 1993a), who referred to the capital securing the value of bank net assets $^{1}$. Merton and Perold, specifying a level of such capital, assumed that it should be the lowest amount that need to be invested in order to hedge a possible depreciation of net assets, taking into account a rate of return that can be achieved by investing these assets in risk-free investment (Merton \& Perold, 1993a). In banks, a minimum level of capital exposed to the expected risk is defined as regulatory capital (Basel Committee on Banking Supervision, 2010; Elizalde \& Pepullo, 2007). Since 1988, the Basel Committee on Banking Supervision has been the institution setting capital exposure for bank risk ${ }^{2}$. It constantly monitors a level of banks' own funds (risk capital) core and supplementary - depending their value on a scale and nature of bank risk, as well as changing an internal structure of risk capital. The first document, defined as the Basel Capital Accord, was based on the measurement of credit risk, assuming that the capital requirement for this risk should amount to at least eight percent. In 1996, the Capital Accord was substantially modified by introducing an additional exposure of bank capital to market risk. In 1999, there was appeared a proposal for the New Basel Capital Accord, called as Basel II. Its standard was finally adopted in 2004, indicating that with respect to own funds (Basel Committee on Banking Supervision, 2004) that a minimum capital requirement should also apply to operational risk, it is necessary to improve the measurement of bank risk, and banks should secure their overall risk cover by the so-called internal capital.

The approach to bank risk capital in these regulations primarily increases the scope of risk retention. Maintaining bank financial reserves, which in the situation of bank risk escalation can be used to cover its negative effects, refers to bank capital, exposed to credit, market and operational risk. The functions of this capital in banks essentially are fulfilled by their own funds: core and

\footnotetext{
${ }^{1}$ Net asset value is gross asset value less liabilities to banking customers.

${ }^{2}$ It operates under the auspices of the Bank for International Settlements in Basel.
} 
supplementary. A level and structure of this bank capital are determined in accordance with the applicable regulatory standards.

Therefore, risk retention is not the only condition for creating own funds in the Polish banking sector. However, prudential regulations strongly determine their level, structure and sources of origin. Bank risk capital is essentially of a balance sheet nature, but its value depends on the quality of both balance sheet and off-balance sheet banking assets.

Basel III, supplementing the New Basel Capital Accord after the global financial crisis, imposed on banks additional requirements to maintain the so-called capital buffers and increase liquidity risk control. At the same time, since implementation of the "CRD IV package" (Regulation, 2013; Directive 2013), banks have controlled the leverage ratio and its components. Therefore, the experience shows that although the minimum capital requirement - the so-called banks' regulatory capital, has changed in relation to bank risk categorization, it does not cover all its forms. Banks' own capital remains lower than the required risk capital. It should, admittedly, correspond to the forms of risk indicated in prudential regulations, however its adequacy is doubtful.

The new approach to bank risk capital was undoubtedly reflected in the Basel II regulations, implementing the concept of internal capital into a banking sector. This capital, also referred as economic capital, requires from banks to assess and permanently maintain value, type and structure of internal capital, corresponding to the hedged type and a scale of risk that banks are or may be expose (Directive, 2013/36/EU). Estimation of economic capital value, in the Capital Accord implemented in 2004, was made conditional on the methods of risk measurement, recognizing that the essence of risk capital is best reflected by the Value-at-Risk (VAR) concept (Basel Committee on Banking Supervision, 2005).

Banks often shape a level of risk capital by creating target and general provisions. Target provisions are used to modify a value of receivables in the balance sheet and off-balance sheet records (Marcinkowska, 2007). On the other hand, banks' general provisions are created for unidentifiable risk of banking operations. Banks create these reserves in accordance with accounting rules, but nevertheless they are followed by their own motives. So risk retention, secured by bank reserves, is not sufficiently effective.

Bank risk capital more and more often is created in banks through risk transfer (see Table 1).
Typical examples of pure bank risk transfer are bank loans insurance or derivatives. They cause that in the case of negative effects of risk, insurance or future contract partner (E. J. Vaughan \& T. Vaughan, 2003) is obliged to provide financial resources that offset incurred financial losses. The transfer of bank risk may take place through more modern forms resulting from the securitization of banks' financial assets (Pyka, 2012). Thus, a bank, in accordance with the results of its risk assessment, choosing retention or transfer as a method of risk control, automatically extends a resource of held risk capital. In this case, sources of risk capital may also be both balance sheet as well as off-balance sheet.

Table 1. Risk capital in a banking enterprise (source: own work)

\begin{tabular}{|c|c|l|l|}
\hline $\begin{array}{c}\text { Type of } \\
\text { bank } \\
\text { risk }\end{array}$ & $\begin{array}{c}\text { Form of } \\
\text { risk } \\
\text { capital } \\
\text { creation }\end{array}$ & $\begin{array}{c}\text { Nature of } \\
\text { bank } \\
\text { capital }\end{array}$ & $\begin{array}{l}\text { Type of bank } \\
\text { funds } \\
\text { creating risk } \\
\text { capital }\end{array}$ \\
\hline $\begin{array}{c}\text { Expected } \\
\text { bank risk }\end{array}$ & $\begin{array}{l}\text { Bank risk } \\
\text { retention }\end{array}$ & $\begin{array}{l}\text { Balance } \\
\text { sheet } \\
\text { capital }\end{array}$ & $\begin{array}{l}\text { Bank's own } \\
\text { funds from } \\
\text { balance sheet } \\
\text { assets: } \\
\text { - core } \\
\text { - supplemen- } \\
\text { tary } \\
\text { Bank re- } \\
\text { serves: } \\
\text { target pro- } \\
\text { visions } \\
\text { general } \\
\text { provisions } \\
\text { Other capital } \\
\text { buffers }\end{array}$ \\
\hline $\begin{array}{l}\text { Unex- } \\
\text { bected }\end{array}$ & $\begin{array}{l}\text { Bank risk } \\
\text { retention }\end{array}$ & $\begin{array}{l}\text { Balance } \\
\text { sheet } \\
\text { capital }\end{array}$ & $\begin{array}{l}\text { Internal capi- } \\
\text { tal for bank } \\
\text { risk of finan- } \\
\text { cial assets }\end{array}$ \\
\hline $\begin{array}{l}\text { Expected } \\
\text { bank risk }\end{array}$ & $\begin{array}{l}\text { Bank risk } \\
\text { retention }\end{array}$ & $\begin{array}{l}\text { Off-bal- } \\
\text { ance } \\
\text { sheet } \\
\text { capital }\end{array}$ & $\begin{array}{l}\text { Own funds at } \\
\text { risk from off- } \\
\text { balance sheet } \\
\text { assets }\end{array}$ \\
\hline risk & $\begin{array}{l}\text { Off-bal- } \\
\text { ance } \\
\text { sheet } \\
\text { capital }\end{array}$ & $\begin{array}{l}\text { Securitization } \\
\text { instruments } \\
\text { of bank as- } \\
\text { sets } \\
\text { Credit deriva- } \\
\text { tives }\end{array}$ \\
\hline
\end{tabular}

After the global financial crisis, bank risk capital is a subject to much more specific control of national and international supervisory institu- 
tions. In prudential regulations, there was a significant increase in the quality of bank capital, growth of the minimum capital requirements, as well as additional capital buffers appeared (Szpunar, 2016). Analyzing bank risk capital, its varied purposefulness should be emphasized. External prudential regulations are directed primarily on the protection of bank deposits. Retention and transfer of risk in banks, enforced by prudential norms, should however be integrated with protection of shareholders' capital value and running their effective operating activities. For this reason, creation of bank risk capital is an important, with increasingly significance, element of the integrated risk management of banking enterprises.

After the global financial crisis, proportions in the creation of bank risk capital have significantly changed. The role of capital created through risk transfer has been reduced, while the role of risk retention has been increased. As a consequence of these changes, the problem is weakening efficiency of bank capital.

\section{Methodology}

Analysis of the effectiveness of risk capital was fully focused on the assessment of an impact of a value of own funds on Polish banking sector profitability. Selecting the sample for the research study, the analysis did not cover all banking sector enterprises (comprehensive/exhaustive research), but some units of the population were selected (Klepacki, 1984) - i.e. those of the most significant importance for the sector. Research on the effectiveness of risk capital in the Polish banking sector have been divided into two stages. This two-stage approach resulted from the fact that an attempt was made to assess the effectiveness of risk capital both at a level of the whole banking sector and individual banking institutions in Poland. Therefore, it enabled the analysis of correlation between a level of banks' own funds and their profitability at a macroeconomic level (of the entire banking sector) and microeconomic level (individual banks), thereby enabled full recognition of the analyzed phenomenon.

The first stage included the assessment of relations between a value of own funds of the whole banking sector in Poland and one of the basic position illustrating efficiency of banks' operations i.e. a value of their net profit. Measures to assess the effectiveness of bank's operations are different (Kopiński, 2008; Niewiadoma, 2007/2008). However, it is assumed that net profit is the most important position (Juszczyk, Balina, Różyński, \&
Pochopień, 2013). Net profit favors creating market value, paying out dividends to shareholders and determines a level of self-financing of bank's development. Net profit is also an important source of financing own funds. These arguments determined the use of net profit to assess effectiveness of risk capital in the banking sector in Poland. For this purpose, a linear regression function of net profit of the banking sector in Poland relative to a given feature - an amount of risk capital, identified with an amount of own funds estimated to calculate solvency ratio of the whole banking sector, was estimated. Values of regression coefficients as well as linear regression equation were determined. A linear regression equation takes the general form of (linear model) (Rachev, Mittnik, Fabozzi, Focardi, \& Jasic, 2008):

$$
y=a x+b,
$$

where: $a$ - regression coefficient (slope); $b$ - constant of regression (intercept).

Therefore, the first stage allowed an empirical verification of the adopted research hypothesis, which states that in the Polish banking sector there is a positive correlation between net profit and banks' own funds, which constitute an essential component of bank risk capital. First stage of the research also included assessment of statistical significance of the estimated linear regression function using the Student T-test and F-test. This stage also allowed for a substantive assessment of the regression coefficient to verify direction of the regression function (linearly increasing or decreasing function).

The analysis period covered the years of 2002 2016, divided into three research sub-periods:

- 2002-2007 - a period before the global financial crisis - when the emphasis on the issues of capital collateral in the Polish banking sector was marginal,

- 2008-2010 - a period of the crisis escalation and time when consequences of the instability were identified in the form of reduced profitability of the banking sector in Poland,

- 2011-2016 - a later period when, in accordance with EU regulations ("CRD IV package"), banking institutions were obliged to systematically increase a level of own funds that they maintained.

The empirical research aimed to determine a nature of relations between the value of risk capital, represented by the amount of own funds in the Polish banking sector, and the value of generated net profit. 
The second stage of the research concerned the analysis of risk capital effectiveness in individual banking institutions operating in Poland. The research covered selected, the largest commercial banks in Poland, from the point of view of the size of their total assets. Value of own funds of the analyzed banks was assessed in relation to their profitability, measured by basic effectiveness indicators for banking institutions (Nocoń, 2016; Kopiński, 2008).

To assess the effectiveness of risk capital in individual banking institutions, commonly used profitability measures were used:

- an amount of generated net profit,

- Return on Assets (ROA) - an indicator which reflects a quotient of net profit and total assets (Kopiński, 2008; Niewiadoma, 2007/2008),

- Return on Equity (ROE) - an indicator which reflects a quotient of net profit and total equity (Kopiński, 2008; Niewiadoma, 2007/2008).

The efficiency analysis was carried out within separate groups. By the quartile method, analyzed banks were divided into three groups. The first group included $25 \%$ of banks, which were characterized by the lowest level of total own funds. The third group included $25 \%$ of banks with the highest value of total own funds. While, the second group contained $50 \%$ of the studied population, i.e. entities characterized by intermediate values between first and second group. In order to compare the results, in each group there were calculated average values of the tested profitability indicators.

Research period of the risk capital effectiveness analysis in individual banks covered the years of 2006-2016. The year 2006 was recognized as a beginning of the analysis, when EU directives were implemented (Directive, 2006a, 2006b), and imposed on banks the obligation to estimate own funds to assess their capital adequacy. In 2007, these regulations were transferred into Polish law in the form of the Polish Financial Supervision Authority resolutions (the institution responsible for financial supervision in Poland $)^{3}$.

The research material, used at specific stages, included data of the National Bank of Poland for the banking sector and financial statements of individual banks, analyzed in the study.

\section{Results}

In accordance with the adopted methodology, the first stage of the research included an analysis of risk capital effectiveness of the whole banking sector in Poland. Before estimation of a linear regression model, a two-dimensional scatterplot was made. It reflects relations between the variables adopted in the model (see Figure 1). It provides a graphical interpretation of a potential correlation between the analyzed variables. The twodimensional plane illustrates a relation between the independent variable (explanatory variable, variable $\mathrm{X}$ ) - i.e. the value of own funds of the banking sector in Poland and the dependent variable (explained variable, variable Y) - a level of net profit, generated by the banking sector. Points on the graph correspond to individual observations - subsequent years of the analysis of the adopted time series.

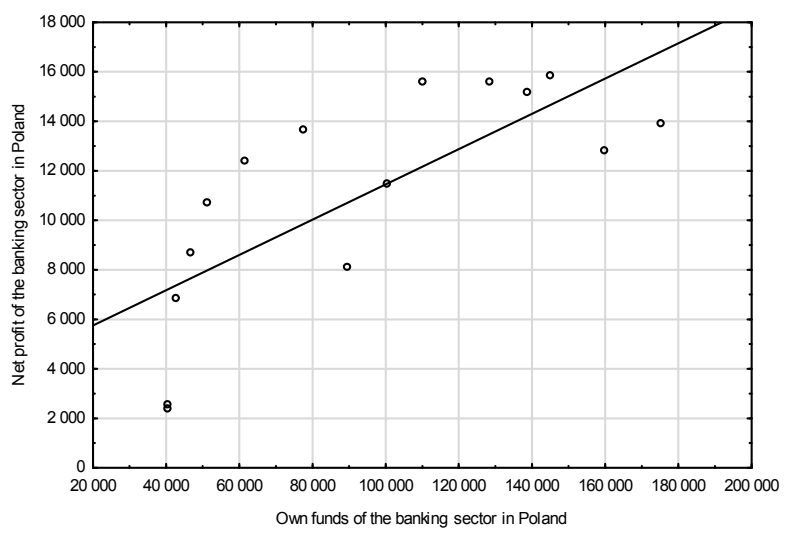

Figure 1. A scatterplot illustrating the relation between own funds and net profit of the banking sector in Poland in the years of 2002-2016 (source: own work)

The scatterplot indicates positive, linear dependence between tested variables, however with different strength. Therefore, it can be concluded that in the analyzed period, an increase of risk capital in the Polish banking sector is accompanied by an increase of its profitability. Determination of strength of this dependence was estimated by conducting further statistical-econometric studies. Their most important part was the estimation of a linear regression model. Table 2 presents the results obtained through carried out estimation.

\footnotetext{
${ }^{3}$ These were not the first regulations regarding capital adequacy, because previously banks in Poland had had other regulations in force regarding a level of capital collateral, simpler and less sensitive to risk. However, those introduced in 2007 were markedly different from the previous ones. They were characterized by a higher degree of sophistication, based on different criteria and methods of capital risk estimation and management.
} 
Table 2. Results of linear regression model estimation (source: own work)

\begin{tabular}{|c|c|}
\hline Specification & $\begin{array}{l}\text { Parameters of the linear } \\
\text { regression model }\end{array}$ \\
\hline $\begin{array}{l}\text { Constant of regression } \\
\text { (b) }\end{array}$ & 4331.508 \\
\hline $\begin{array}{l}\text { Regression coefficient } \\
\text { (a) }\end{array}$ & 0.071249 \\
\hline $\begin{array}{l}\text { Correlation coefficient } \\
(r)\end{array}$ & 0.74665509 \\
\hline $\begin{array}{l}\text { Coefficient of determi- } \\
\text { nation }\left(r^{2}\right)\end{array}$ & 0.55749383 \\
\hline $\begin{array}{l}\text { Standard error of esti- } \\
\text { mation }\end{array}$ & 3095.632 \\
\hline $\begin{array}{l}\text { The value of t-student } \\
\text { statistics }\end{array}$ & $\begin{array}{l}\mathrm{t}_{\alpha 0}=\frac{\hat{\alpha}_{0}}{S\left(\hat{\alpha}_{0}\right)}=2.356911 \\
\mathrm{t}_{\alpha 1}=\frac{\hat{\alpha}_{1}}{S\left(\hat{\alpha}_{1}\right)}=4.046989\end{array}$ \\
\hline $\begin{array}{l}\text { The value of the F sta- } \\
\text { tistics }\end{array}$ & 16.37812 \\
\hline
\end{tabular}

Critical value of t-student test for $n=15$ and $\alpha=0.05$ is equal to $t^{*}=2.160369^{4}$.

Critical value of F-test for $k-1=1, n-k=13, \alpha=0.05$ is equal to $F^{*}=4.6671927136$

p-value $=0.001384112<0.05$ of:

Estimated regression model takes the form

$$
y=0.0712 x+4331.508 .
$$

Therefore, the model shows that an increase of total own funds by $1 \mathrm{mln}$ PLN was associated, ceteris paribus, with an increase of net profit by 71249 PLN. Moreover, it is noted that in the risk capital model, empirical values deviate from theoretical values by an average of $3095.632 \mathrm{mln}$ PLN, which is reflected by the value of the estimated standard error ${ }^{5}$. Its high value indicates a large dispersion of results around the average, which is confirmed by the two-dimensional scatterplot (see Figure 1).
Analysis of the obtained results indicates a strong correlation dependence between net profit and a level of own funds of the banking sector in Poland. Thus, it confirms that an increase of risk capital is accompanied by an increase of net profit of the banking sector. The Pearson correlation coefficient ${ }^{6}$ is at a level of $r_{x y}=0.7467$, which means that there is quite strong positive correlation between tested variables. As a result, along with an increase of the amount of own funds of banks in Poland, the amount of generated net profit increases.

During the conducted research, it turned out that in 2009 an increase in risk capital was accompanied by a decrease in net profit. The Polish banking sector experienced the effects of the spreading financial instability of the global economy, because it was significantly dependent on the results and activities of international capital groups. Therefore, outliers observations have weakened the strength of correlation.

In the estimated linear regression model, based on the obtained coefficient of determination $\left(r^{2}\right)$, it can be stated that with the remaining factors unchanged, a level of own funds explained $55.75 \%$ of the variation of net profit. In other words, the model described the analyzed phenomenon in $55.75 \%$ (weak match).

Evaluation of the significance of the estimated linear regression function was carried out using the Student T-test. The following hypotheses were verified:

$\mathrm{H}_{0}: \alpha_{j}=0$ (statistical irrelevance/a lack of statistical significance);

$\mathrm{H}_{1}: \alpha_{j} \neq 0$ (statistical significance).

The estimated critical value for the significance level of 0.05 and 13 degrees of freedom $(n-k)^{7}$ is $2.160369\left(\mathrm{t}_{\mathrm{kr}}\right)$. Therefore:

- $\left|t_{\alpha 0}\right|=2.356911>2.160369=t_{k r}$, so the parameter $\alpha_{0}$ has a significant impact on the analyzed phenomenon;

\footnotetext{
${ }^{4} t$-statistic is the Student's $t$-distribution with $(n-k)$ degrees of freedom, where $n$ is the number of observations, and $k$ is the number of regressors (including the intercept).

${ }^{5}$ The standard error (SE) of a parameter is the standard deviation of its sampling distribution or an estimate of the standard deviation. The smaller the standard error, the more accurately a parameter, a measure, and a statistics are predicted (Babbie, 2007).

${ }^{6}$ The Pearson product-moment correlation coefficient is used to study the rectilinear relations between variables (Pyka \& Nocoń, 2016). In the literature there are different scales defining strength of the correlation. In the study, it was assumed that for $|\mathrm{r}|$ (Strahl, Sobczak, Markowska, \& Bal-Domańska, 2002):

$\mathrm{r}_{\mathrm{xy}}=0 \quad$ no linear relation, variables are not correlated

$<0.2 \quad$ no correlation

$0.2-0.4 \quad$ weak correlation

0.4-0.7 moderate correlation

$0.7-0.9 \quad$ quite strong correlation

$>0.9 \quad$ very strong correlation.

${ }^{7}$ The number of degrees of freedom is the difference between the number of observations $(\mathrm{n}=15)$ and the number of estimated parameters $(\mathrm{k}=2)$.
} 
- $\left|\mathrm{t}_{\alpha 1}\right|=4.046989>2.160369=\mathrm{t}_{\mathrm{kr}}$, so the parameter $\alpha_{1}$ has a significant impact on the analyzed phenomenon.

Because the $\alpha_{1}$ parameter is a factor determining the amount of net profit, so the conclusion about its significance extends to the conclusion about significance of the variable. Therefore, it can be concluded that a value of risk capital has a significant impact on a value of net profit, generated by the Polish banking sector.

The value of F-statistics and a corresponding level of probabilisty ( $p$-value) also confirm a statistically significant linear dependence between the total own funds of the banking sector and the amount of its net profit. Thus, both results of the Student Ttest and F-test confirm significance of dependences between volatility of own funds of the Polish banking sector and volatility of net profit.

In connection with the identified relatively strong dependence between a level of maintained total own funds of the whole banking sector in Poland and its net profit, the empirical research was deepened by risk capital effectiveness analysis for individual commercial banks (stage II). According to the adopted methodology, banks covered by the study were divided by the quartile method into three groups. In the first group ( $1^{\text {st }}$ quartile), 25\% of analyzed banks were included - such as Getin Noble Bank S.A. and Millenium Bank S.A., i.e. those with the lowest value of own funds as at December 31, 2016 (accordingly on a level of 6 $296.5 \mathrm{mln}$ PLN and $6252.4 \mathrm{mln}$ PLN). The third group ( $3^{\text {rd }}$ quartile) included $25 \%$ of banks with the highest level of own funds. This group consisted of PKO BP S.A. (31 $129.3 \mathrm{mln}$ PLN) and Pekao S.A. (19 $368.6 \mathrm{mln}$ PLN). In turn, the second group ( $2^{\text {nd }}$ quartile) accounted for $50 \%$ of banks, characterized by the values of own funds between first and third group at the end of 2016. This group included: BZ WBK S.A. (14 596.9 mln PLN), mBank S.A. (13 $333.8 \mathrm{mln}$ PLN), ING Bank Śląski S.A. (9 068.1 mln PLN) and BNP Paribas S.A. (7 $634.5 \mathrm{mln}$ PLN).

Figure 2 presents the average level of net profit in the analyzed groups of banks due to a total level of own funds. The conducted research shows that banks from third group, characterized by the highest level of total equity, in the analyzed period obtained definitely the highest average level of net profit. Banks with lower level of risk capital - accordingly from second and third group - generated lower net financial results. This means that the lower level of own funds was accompanied by lower profitability.

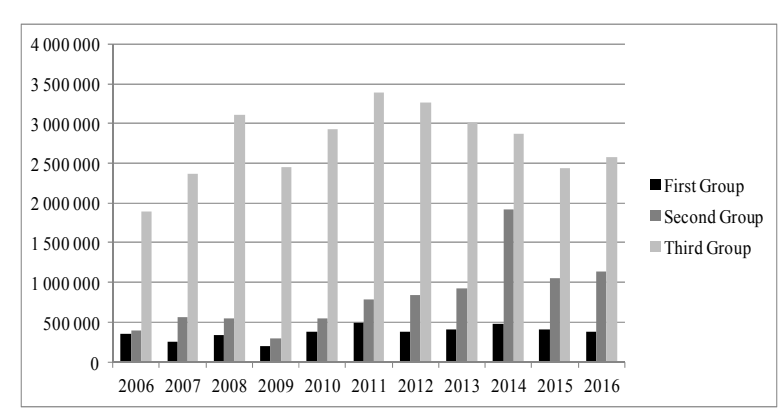

Figure 2. Net profit depending on the total value of own funds (in thous. PLN) (source: own work)

In the further part of the analysis, relation between return on assets and banks' own funds was examined. It can be noticed that banks that accumulated the highest level of risk capital were also characterized by the highest efficiency of using their assets (see Figure 3). With the exception of 2006 and 2007, when the highest values of the average ROA indicator were obtained by banks from the first group, i.e. those with the lowest value of own funds.

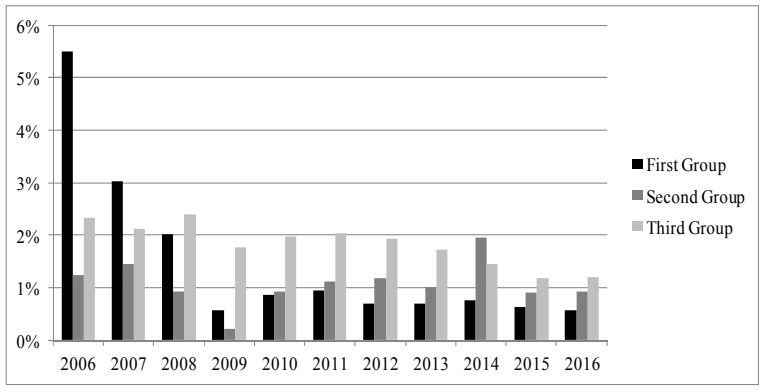

Figure 3. Return on Assets (ROA) depending on the total value of own funds (in percent) (source: own work)

The analysis of empirical data allowed to notice that Getin Noble Bank S.A. as well as Millenium Bank S.A. generated high values of net financial result in relation to the size of their total assets. In the case of Getin Noble Bank S.A., they were a result of running a business according to the new business model, based on the portfolio of loans secured by mortgage and financial assets. The dynamic development of the bank resulted mainly from an intensive growth of its lending activity. In turn, Millenium Bank S.A. continued the previously adopted medium-term strategy, which allowed to strengthen the bank's position on the financial services market, for quantitative and qualitative development of its offer and an increase in lending activity, which improved basic effectiveness indicators. This may mean that in the case of smaller banks, more effective management of 
their assets and liabilities can be observed, which translates into their higher profitability.

Finally, the analysis of dependences between return on equity and an amount of own funds complemented the research concerning the assessment of effectiveness of risk capital for individual banks, classified by the quartile method (see Figure 4). It is noted that in the majority of cases, banks that accumulated the highest level of risk capital, generated in the analyzed period the highest value of ROE indicator, which were higher than in other groups of banks. However, the highest values of return on equity in the years of 20062008 were recorded by banks from the first group, so those with the lowest level of risk capital. In turn, in 2014 banks from the second group recorded the highest average value of ROE at a level of $18.03 \%$, also higher than banks from the third group - those with the highest level of own funds. The lack of value for the second group in 2009 results from the fact that one of the banks in this group (BNP Paribas S.A.) recorded a negative net financial result, which decreased the average value for the whole group of banks.

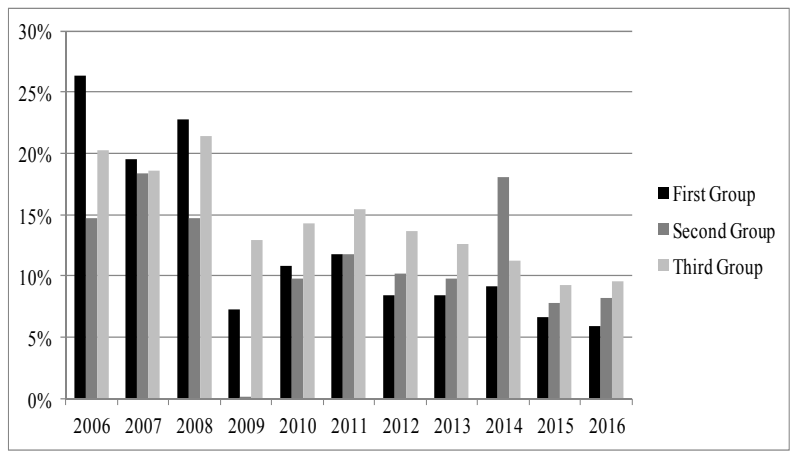

Figure 4. Return on Equity (ROE) depending on the total value of own funds (in percent) (source: own work)

The carried out analysis and assessment dependence between return on equity and an amount of own funds only partially confirms previous correlation conclusions, obtained from estimation of the linear regression model for the whole banking sector. At the beginning of the analyzed period, banks with a lower level of risk capital were able to achieve a higher return on assets and return of equity rather than those that were characterized by the highest level of total own funds. At the same time, it should be emphasized that an increase of risk capital in subsequent years in all three groups of banks did not impact on an increase of their profitability, examined both by ROA and ROE indicators.

\section{Conclusions}

The bank risk capital analysis, directed at identification of the main sources of its origin, indicated that it is a complex category. Risk capital is created by banks through its retention as well as transfer. These methods secure their expected losses, resulting from various types of risk, specified in the Basel regulations. Regulatory capital created in banks is only liable for identified losses of materializing bank risk. Bank secure high exposure to specific risk by creating economic (internal) capital - see Figure 5.

The global financial crisis has confirmed a fairly common opinion that it is the most difficult to secure "exceptional" losses, arising from unidentified bank risk. Therefore, Basel III increases the area of identified bank risk and methods of its protection. The research have indicated that by this way banks limit risk transfer for its retention. Thus, banks' own funds increase, constituting a main subject of the empirical research.

The empirical research carried out in the Polish banking sector have shown that there is positive, linear dependence between own funds and its net profit. The assessment of this dependence was made by estimating a linear regression function of net profit in relation to the amount of risk capital, identified with the value of own funds of the banking sector in Poland. Quite strong positive correlation between the analyzed variables allows to conclude that an increase in risk capital is accompanied by an increase in net profit of the banking sector.

Empirical research conducted for the Polish banking sector are a very interesting example confirming the existence of positive correlation between banks' own funds and efficiency of their operations. At the same time, they can be a reference point for further in-depth research in the EU countries, in particular Central and Eastern European countries, which represent similarity of the structure of their banking sectors. Especially that, risk capital in the Polish banking sector is created on principles applicable in other European Union countries. The obtained results constitute a significant contribution to the discipline of finance and economic sciences. Indeed, they point out that despite costs associated with the process of increasing own funds, banks that own a larger level of capital generate higher profitability. Therefore, the results are innovative, refuting the existing view of only a negative impact - increasing costs - resulting from the need to increase the value of risk capital in a banking sector. 


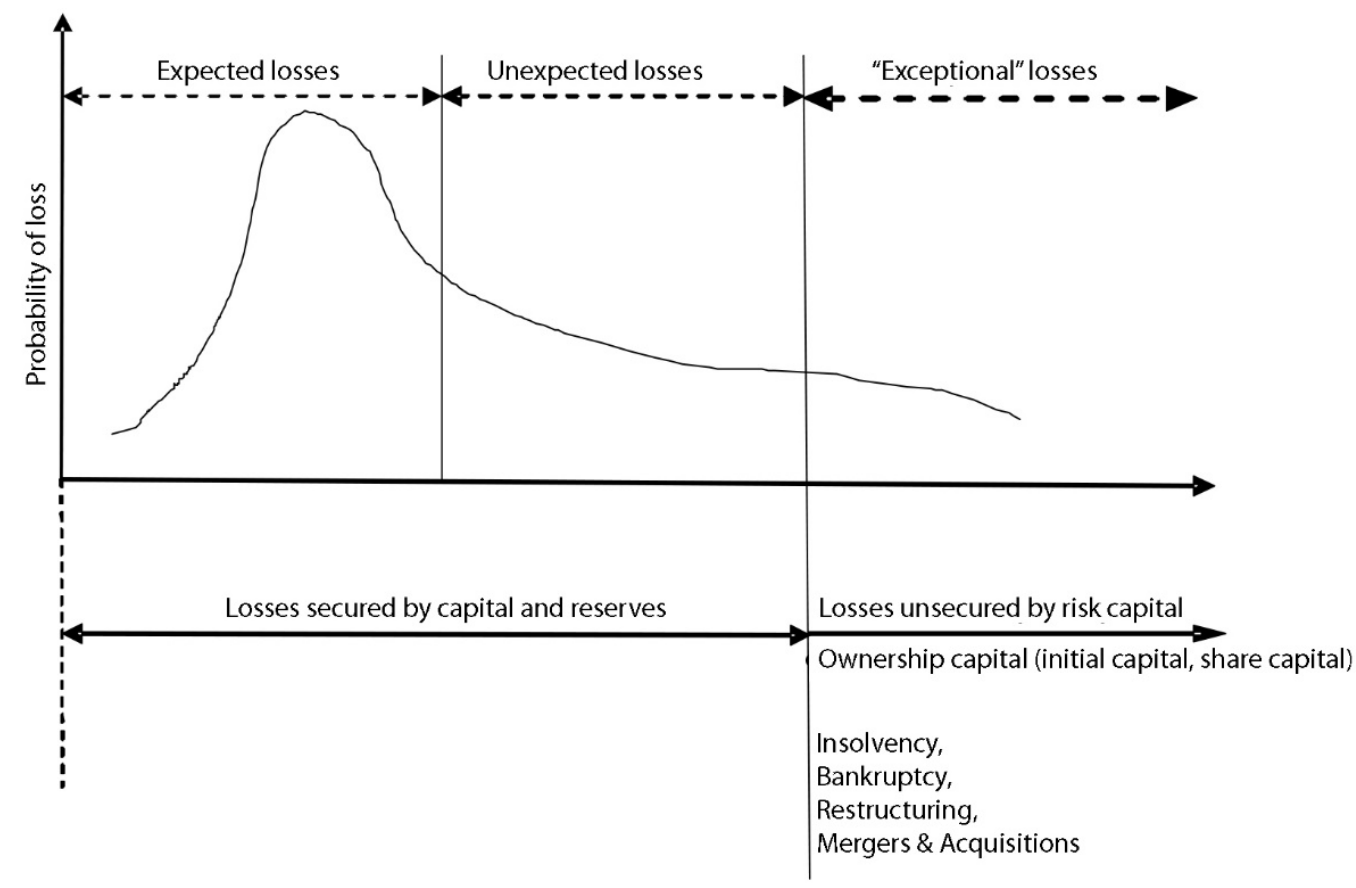

Figure 5. Expected and unexpected losses due to bank risk (source: own work)

Therefore, the carried out research allow to confirm the research hypothesis that in the Polish banking sector there is a positive correlation between net profit and banks' own funds, which constitute an essential component of bank risk capital. Nevertheless, in the view of conclusions reached from the in-deepth empirical research, it seems justified their further continuation towards:

- extending the research period as further prudential regulations are implemented in relation to bank risk capital,

- expansion of the research sample - by smaller commercial banks in Poland from the point of view of a size of their assets,

- comparative analysis of the results of linear regression model estimation obtained for the Polish banking sector with the results for other EU member states, which are also obliged comply with the regulations on capital adequacy, included in the "CRD IV regulatory package".

\section{References}

Aaron, M., Armstrong, J., \& Zelmer, M. (2012). An overview of risk management at Canadian banks. Financial System Review, 1, 39-47.

Altunbas, Y., Binici, M., \& Gambacorta, L. (2017). Macroprudential policy and bank risk. BIS Working Papers 646, June.
Altunbas, Y., Manganelli, S., \& Marques-Ibanez, D. (2011). Bank risk during the financial crisis. Do business models matter?. ECB Working Paper Series 1394, November.

Apostolik, P., Donohue, Ch., \& Went, P. (2009). Foundations of banking risk. An overview of banking, banking risks and risk-based banking regulation. New Jersey: Wiley Finance, John Wiley \& Sons.

Babbie, E. (2007). Badania spoteczne w praktyce [The practice of social research]. Warsaw: PWN.

Banks, E. (2004). Alternative risk transfer: integrated risk management through insurance, reinsurance and capital market. Chichester: John Wiley. https://doi.org/10.1002/9781118673270

Basel Committee on Banking Supervision. (2004). International convergence of capital measurement and capital standards. A revised framework. BIS, Basel, June.

Basel Committee on Banking Supervision. (2005). Amendment to the capital accord to incorporate market risks. BIS, Basel, November.

Basel Committee on Banking Supervision. (2010). Basel III: a global regulatory framework for more resilient banks and banking systems. Bank for International Settlements, Basel, December.

Bessis, J. (2015). Risk management in banking. Chichester: Wiley Finance, June.

Boyd, J. H., \& De Nicoló, G. (2005). The theory of bank risk taking and competition revisited. The Journal of Finance, 60(3), June,1329-1343. https://doi.org/10.1111/j.1540-6261.2005.00763.x

Culp, C. (2002a). Contingent capital: integrating corporate financing and risk management. Journal of Applied Corporate Finance, 15(1), Spring, 46-56. https://doi.org/10.1111/j.1745-6622.2002.tb00340.x

Culp, C. (2002b). The art of risk management, alternative risk transfer, capital structure, and the convergence of insurance and capital markets. New York: John Wiley \& Sons. 
Dionne, G. (2013). Risk management: history, definition, and critique. Risk Management and Insurance Review, 16(2), 147-166. https://doi.org/10.1111/rmir.12016

Directive 2006/48/EC of the European Parliament and of the Council of 14 June 2006 relating to the ta king up and pursuit of the business of credit institutions. Official Journal of the European Union, L 177/1, 30.06.2006.

Directive 2006/49/EC of the European Parliament and of the Council of 14 June 2006 on the capital adequacy of investment firms and credit institutions. Official Journal of the European Union, L 177/201, 30.06.2006.

Directive 2013/36/EU of the European Parliament and of the Council of 26 June 2013 on access to the activity of credit institutions and the prudential supervision of credit institutions and investment firms, amending Directive 2002/87/EC and repealing Directives 2006/48/EC and 2006/49/EC (1).

Doherty, N. A. (2000). Integrated risk management: techniques and strategies for reducing risk. New York: McGraw-Hill.

Doherty, N. A. (2005). Risk management, risk capital, and the cost of capital. Journal of Applied Corporate Finance, June, 119-123. https://doi.org/10.1111/j.1745-6622.2005.00052.x

Duliniec, A. (2011). Finansowanie przedsiębiorstwa. Strategie $i$ instrumenty [Financing the enterprise. strategies and instruments]. Warsaw: PWE.

Elizalde, A., \& Pepullo, R. (2007). Economic and regulatory capital in banking: what is the difference?. International Journal of Central Banking, 3(3), September, 87-117.

Ennouri, W. (2013). Risks management: new literature review. Polish Journal of Management Studies, 8, 288297.

European Standard. (2010). ISO/IEC 31010:2009 Ed. 1.0: Risk management - Risk assessment techniques.

Graham, A. (2008). Integrated risk management. Implementation guide. Retrieved from http://post.queensu.ca/ $\sim$ grahama/publications/TEXTPDF.pdf

Iacob, V. S. (2014). Risk management and evaluation and qualitative metod within the project. Ecoforum 3, 1(4), 60-67.

Ishikawa, T., Yamai, Y., \& Ieda, A. (2003). On the risk capital framework of financial institutions. IMES Discussion Paper Series 2003-E-7, Bank of Japan.

Jajuga, K., Karaś, M., Kuziak, K., \& Szczepaniak, W. (2017). Ryzyko systemu finansowego. Metody oceny i ich weryfikacja w wybranych krajach [Risk of financial system. Methods of assessment and their verification in selected countries]. Materials and Studies, 329, NBP.

Juszczyk, S., Balina, R., Różyński, J., \& Pochopień, J. (2013). Zmienność funduszy własnych a efektywność banków spółdzielczych (Variability of equity versus efficiency of cooperative banks). The Journal of Management and Finance, 11(2) Part 1, 230-242.

Kaplan, R., \& Mikes, A. (2016). Risk management-the revealing hand. Journal of Applied Corporate Finance, 28(1), 8-18. https://doi.org/10.1111/jacf.12155

Klepacki, B. (1984). Wybór próby w badaniach ekonomiczno-rolniczych [Selection of the sample in economic and agricultural research]. Warsaw: SGGW Printing House.

Klimczak, K. M. (2007). Risk management theory: a comprehensive empirical assessment. Kozminski Working Papers Series 01-2007, Warsaw.

https://doi.org/10.2139/ssrn.1031850

Kopiński, A. (2008). Analiza finansowa banku [Financial analysis of a bank]. Warsaw: PWE.
Marcinkowska, M. (2007). Ocena działalności instytucji finansowych [Assessment of the financial institutions' activity]. Warsaw: Difin.

Marcinkowska, M. (2010). Standardy kapitałowe banków. Bazylejska Nowa Umowa Kapitałowa w polskich regulacjach nadzorczych [Capital standards of banks. The New Basel Capital Accord in Polish supervisory regulations]. Warsaw: Regan Press.

Matten, C. (2000). Managing bank capital: capital allocation and performance measurement (2nd ed.). Chichester: John Wiley \& Sons.

McCuaig, B. (2008). Fundamentals of GRC: mastering risk assessment [White Paper]. Thomson Reuters.

Merton, R. C., \& Perold, A. F. (1993a). Management of risk capital in financial firms. Harvard Business School, W.P. 38.

Merton, R. C., \& Perold, A. F. (1993b). Theory of risk capital in financial firms. Journal of Applied Corporate Finance, 6, 16-32. https://doi.org/10.1111/j.1745-6622.1993.tb00231.x

Moreno, R. (2006). The changing nature of risks facing banks, in the banking system in emerging economies: how much progress has been made?. BIS Papers, 28, 67-98.

Niewiadoma, M. (2007/2008). Wielopoziomowy system kontroli banków [Multi-level system of bank control]. Warsaw: CeDeWu Platinium.

Nocoń, A. (2016). System reagowania wspótczesnych banków centralnych na niestabilność sektora bankowego [The response system of modern central banks against banking sector instability]. Warsaw: Difin.

OECD. (2014). Risk management and corporate governance. Corporate Governance, OECD Publishing.

Protivity. (2006). Guide to enterprise risk management. Retrieved from http://www.ucop.edu/enterprise-riskmanagement/_files/protiviti_faqguide.pdf

Purdy, G. (2010). ISTO 31000: 2009 - setting a new standard for risk management. Risk Analysis, 30(6), 881-886. https://doi.org/10.1111/j.1539-6924.2010.01442.x

Pyka, I. (2012). Rynkowe instrumenty finansowe $w$ alokacji kapitalu bankowego [Market financial instruments in allocation of bank capital]. Warsaw: Difin.

Pyka, I., \& Nocoń, A. (2016). Dynamics of lending activity of Polish banking sector towards low interest rate policy of central banks. Tranformations in Business \& Economics, 15(2A-38A), 415-433.

Pyle, D. H. (1997). Bank risk management: theory. UCBerkley, Research Program in Finance, Working Paper RPF-272, July.

Rachev, S. T., Mittnik, S., Fabozzi, F. J., Focardi, S., \& Jasic, T. (2008). Regression analysis. Chapter III in F. J. Fabozzi, Handbook of finance (pp. 5-59). New Jersey: John Wiley \& Sons. https://doi.org/10.1002/9780470404324.hof003059

Ratliff, R., \& Hanks, S. (1992). Evaluating risk. Managerial Auditing Journal, 7(5), 26-32. https://doi.org/10.1108/02686909210017883

Regulation (EU) No 575/2013 of the European Parliament and of the Council of 26 June 2013 on prudential requirements for credit institutions and investment firms and amending Regulation (EU) No 648/2012 (1).

Rejda, G. E. (2001). Principles of risk management and insurance. Addison Wesley Longman, International Edition.

Santomero, A. M. (1997). Commercial bank risk management: an analysis of the process. Pennsylvania: The 


\section{EFFECTIVENESS OF RISK CAPITAL (OWN FUNDS) IN THE POLISH BANKING SECTOR \\ IN THE YEARS OF 2002-2016}

Wharton School, University of Pennsylvania. Retrieved from https://pdfs.semanticscholar.org/ 7119/eefc281c33ddbaa249bcaa90757285117737.pdf

Schieg, M. (2006). Risk management in construction project management. Journal of Business Economics and Management, 7(2), 77-83.

Strahl, D., Sobczak, E., Markowska, M., Bal-Domańska, B. (2002). Econometric modeling with Excel. Wroclaw: Wrocław University of Economics Printing House.

Szpunar, P. (2016). Regulacje makrostrożnościowe sektora bankowego [Macroprudential regulations of a banking sector]. In T. Czerwińska, K. Jajuga (Sc. Ed.). Ryzyko instytucji finansowych - współczesne trendy i wyzwania [Risk of financial institutions - modern trends and challenges]. Warsaw: C.H. Beck.

Szustak, G. (2017). Wielopłaszczyznowy system kontroli ryzyka bankowego [Multi-faceted system of bank risk control]. Warsaw: Difin.

The Conference Board of Canada. (2003). Risk management: moving the framework to implementation. Keys to successful risk management implementation strategy. Deloitte \& Touche, October.
The National Archives. (2017). Risk assessment handbook. United Kingdom. Retrieved from http://www.nationalarchives.gov.uk/documents/information-management/risk-assessment-handbook.pdf

Van Greuning, H., \& Brajovic Bratanovic, S. (2009). Analyzing banking risk. A framework for assessing corporate governance and risk management (3rd ed.). Washington D.C.: The World Bank Publishing House. https://doi.org/10.1596/978-0-8213-7728-4

Vaughan, E. J., \& Vaughan, T. (2003). Fundamentals of risk and insurance. New York: John Wiley \& Sons.

Versluis, V. (2011). Risk management and decision theory. Retrieved from http://www3.hro.nl/PageFiles/ 80221/FINAL.pdf

Williams, Jr. C. A., \& Heins, R. M. (1989). Risk management and insurance. New York: McGraw-Hill.

Županović, I. (2014). Sustainable risk managemnt in the banking sector. Journal of Central Banking Theory and Practice, 3(1), 81-100. https://doi.org/10.2478/jcbtp-2014-0006

Żółtkowski, W. (2017). Zarządzanie ryzykiem w matym banku - w kontekście zmieniających się regulacji nadzorczych [Risk management in a small bank - in the context of changing supervisory regulations]. Warsaw: CeDeWu. 